\title{
Realistic Mathematics Education untuk Meningkatkan Kemandirian Belajar Matematika
}

\author{
Renika Arisinta ${ }^{1}$, Abdur Rahman As'ari², Cholis Sa'dijah ${ }^{2}$ \\ ${ }^{1}$ Pendidikan Dasar-Universitas Negeri Malang \\ ${ }^{2}$ Pendidikan Matematika-Universitas Negeri Malang
}

\begin{tabular}{l}
\hline INFO ARTIKEL \\
\hline Riwayat Artikel: \\
Diterima: 24-04-2019 \\
Disetujui: 22-06-2019 \\
\hline
\end{tabular}

Kata kunci:

realistics mathematics education; self-regulated;

mathematics;

realistics mathematics education;

kemandirian belajar;

matematika

\begin{abstract}
This study aims to describe the Realistics Mathematics Education (RME) approach in increasing the independence of students' mathematics learning in the material area and around square and rectangle. This type of research was classroom action research. The subject of this study were fourth grade students of Elementary School consisting of 29 students. Learning devices in this study were Learning Implementation Plans and Group Worksheets while the instruments used in this study are observation sheets of student learning independence, teacher observation sheets, questionnaires, and interview guidelines. The results of the study showed that the RME approach that was packaged by giving problems in the form of written or unwritten stories that enabled students to find different solutions/answers and using manipulative media could improve student learning independence with the average student categorized well.
\end{abstract}

ABSTRAK

\begin{abstract}
Abstrak: Penelitian ini bertujuan untuk mendeskripsikan pendekatan Realistics Mathematics Education dalam meningkatkan kemandirian belajar matematika siswa pada materi luas dan keliling persegi dan persegi panjang. Jenis penelitian ini merupakan penelitian tindakan kelas. Subjek penelitian ini yaitu siswa kelas IV yang terdiri dari 29 siswa. Perangkat pembelajaran pada penelitian ini yaitu Rencana Pelaksanaan Pembelajaran dan Lembar Kerja Kelompok, sedangkan instrumen yang digunakan dalam penelitian ini yaitu lembar observasi kemandirian belajar siswa, lembar observasi guru, angket, dan pedoman wawancara. Hasil penelitian menunjukkan bahwa pendekatan RME yang dikemas dengan pemberian permasalahan berupa cerita secara tertulis maupun tidak tertulis yang memungkinkan siswa menemukan berbagai solusi/jawaban yang berbedabeda dan menggunakan media manipulatif dapat meningkatkan kemandirian belajar siswa dengan rata-rata siswa berkategori baik.
\end{abstract}

\section{Alamat Korespondensi:}

\section{Renika Arisinta}

Pendidikan Dasar

Universitas Negeri Malang

Jalan Semarang 5 Malang

E-mail: arisinta.sinta@gmail.com

Matematika dapat memberikan kesenangan dan kenyamanan serta bermakna bagi siswa jika siswa menyadari bahwa matematika adalah alat untuk memecahkan masalah (Papadakis, 2017). Siswa yang yakin bahwa matematika merupakan alat dalam memecahkan permasalahannya akan memiliki kemauan untuk belajar matematika (Laurens, 2018) lalu menumbuhkembangkan sikap kemandirian belajar siswa. Siswa dapat menyadari hal tersebut, guru harus mengetahui dan memanfaatkan pengetahuan awal yang telah dimiliki siswa sehingga guru dapat membantu siswa dalam mempelajari pengalaman yang akan dipelajarinya (Sa'dijah, 2011). Kemandirian belajar memungkinkan siswa untuk merencanakan dan mengatur informasi linguistik, untuk memahami hubungan antara konsep, dan kemudian memilih operasi aritmatika dengan benar sehingga siswa dapat mengembangkan kemandirian belajar yang lebih besar daripada kemampuan akademik (Vula et al., 2017). Kemandirian merupakan salah satu faktor terpenting yang memengaruhi keberhasilan akademik siswa (Prayekti, 2015; Bozpolat, 2016). Selain itu, kemandirian dapat didefinisikan sebagai suatu tindakan yang tidak bergantung dengan orang lain dalam menyelesaikan permasalahan terkait tugas belajarnya (Kemendiknas, 2010). Dengan demikian, perlunya guru dalam mengembangkan kemandirian belajar siswa karena memiliki manfaat jangka panjang pada siswa di masa datang.

Hasil wawancara guru kelas IV pada tanggal 25 Agustus 2018 di SDN Sumbertaman I Probolinggo terkait kemandirian belajar siswa ketika mengerjakan tugas kelompok pada pelajaran Matematika didapatkan hasil bahwa (1) siswa kurang memperhatikan pembelajaran matematika terutama pada materi luas dan keliling bangun datar; (2) siswa kurang berani dalam mengutarakan pendapatnya dan bertanya kepada guru ataupun teman; (3) penugasan yang diberikan guru kurang memberikan kesempatan siswa untuk menemukan jawaban dalam berbagai cara ataupun jawaban; (4) guru jarang memberikan tugas kelompok kepada siswa; (5) selama pemberian tugas secara berkelompok, masih terdapat siswa yang kurang berusaha dalam mengerjakan 
dan berkontribusi dalam menyelesaikan tugas, seperti mencontek; (6) pengerjaan terhadap tugas kelompok masih didominasi oleh anak yang pintar. Peneliti pun menindaklanjuti hasil dari wawancara terhadap guru kelas IV SDN Sumbertaman I Probolinggo berjumlah 29 siswa dengan jumlah siswa laki-laki 15 dan siswa perempuan 14. Peneliti melakukan pra penelitian pada tanggal 28 Agustus 2018 untuk mengobservasi kemandirian belajar siswa dengan memberikan tugas kelompok terkait materi keliling dan luas persegi dan persegipanjang dengan media kertas berpetak. Tugas yang diberikan dan memungkinkan siswa dalam menemukan cara yang berbeda-beda. Peneliti melakukan pengamatan kemandirian belajar siswa yang meliputi berani ketika mengeluarkan pendapat dan berani ketika bertanya, berkontribusi dalam kelompok dan berusaha menemukan jawaban/solusi, dan memperhatikan selama pembelajaran. Hasil pengamatan yang ditunjukkan pada prapenelitian terdapat sepuluh siswa (35\%) dengan kriteria "kurang" dalam kemandirian belajar, lima siswa (18\%) dengan kriteria "cukup" dalam kemandirian belajar, enam siswa (21\%) dengan kriteria "baik" dalam kemandirian belajar, dan tujuh siswa (26\%) dengan kriteria "sangat baik" dalam kemandirian belajar.

Peneliti juga melakukan wawancara pada siswa terkait tugas yang diberikan. Berikut kesimpulan dari hasil wawancara siswa kelas IV SDN Sumbertaman I yang dirasa kurang muncul kemandiriannya pada tanggal 26 Agustus 2018 yaitu (1) awalnya siswa mengaku bahwa mereka kesulitan dan bingung dengan tugas yang diberikan, namun setelah dijelaskan, siswa mulai memahami tugas yang diberikan; (2) terdapat beberapa siswa kurang memperhatikan pembelajaran karena dirinya merasa bosan ketika tidak bisa menemukan jawaban dari tugas yang diberikan; (3) beberapa siswa terlihat kurang berani bertanya dan mengungkapkan pendapatnya karena siswa merasa ragu/takut salah.

Peneliti mencoba mendiskusikan hasil dari observasinya kepada guru kelas yang melihat aktivitas guru ketika memberikan tugas. Guru berpendapat bahwa ketika tugas diberikan (1) awalnya siswa terlihat kurang memahami tugasnya, mungkin mereka belum terbiasa diberikan tugas dengan memilih sendiri keliling yang akan mereka buat. Namun, beberapa siswa tertantang untuk menemukannya dengan bantuan kertas berpetak yang diberikan. Meskipun beberapa siswa yang lain masih terlihat diam dan bermain sendiri; (2) beberapa siswa lebih berani bertanya dan berpendapat meskipun hanya ketika peneliti berada di dekat siswa tersebut; (3) hampir setengah perhatian siswa masih belum fokus terhadap guru ketika menjelaskan tugas yang diberikan, mungkin media yang digunakan harus dikemas lebih menarik sehingga siswa lebih tertarik; (4) kontribusi siswa terlihat masih individual, namun beberapa teman yang kurang bisa sudah berani bertanya kepada teman yang bisa; (5) siswa telihat lebih mandiri setelah menggunakan pendekatan RME.

Kesimpulan dari permasalahan yang muncul di kelas IV SDN Sumbertaman I yang telah didiskusikan bersama dengan guru kelas yaitu siswa terlihat lebih mandiri dari sebelum menggunakan pendekatan RME, namun terdapat kekurangan yang perlu diperbaiki ketika melaksanakan penelitian selanjutnya. Pertama, guru masih kurang dalam menghubungkan tugas yang diberikan dengan kehidupan sehari-hari siswa. Kedua, media yang digunakan dikemas lebih menarik. Ketiga, guru kurang dalam memberikan kesempatan kepada siswa untuk berpikir sesuai dengan konsep yang telah dimiliki ataupun dengan caranya sendiri.

Pembelajaran matematika ditekankan pada aktivitas siswa dalam mencari, menemukan dan membangun sendiri pengetahuannya yang diperlukan, sehingga menjadi pengalaman belajar bagi setiap individu (Sa'dijah, 2013). Pembelajaran dengan mengaitkan permasalahan yang kontekstual harus disesuaikan dengan tingkat perkembangan siswa sehingga membantu siswa dalam mencapai keberhasilan akademik. Piaget berpendapat bahwa tingkatan perkembangan kognitif siswa SD pada usia 6 sampai 11 tahun masih dalam tahap perkembanagn kognitif operasional kongkret dimana siswa dapat menyelesaikan permasalahan yang ada disekitarnya (Crain, 2007). Cara mengajar guru sangatlah menentukan sikap siswa dalam suatu pembelajaran termasuk kemandirian dalam belajar siswa (Caruth, 2019). Tugas guru dalam NCTM (National Council of Teachers of Mathematics) menciptakan suatu pembelajaran yang mendorong siswa dalam berpikir, bertanya, menyelesaikan soal, dan mendiskusikan ide-ide, strategi, dan penyelesaian siswanya (Walle, 2008). Cara mengajar guru sangatlah menentukan sikap siswa dalam suatu pembelajaran termasuk kemandirian dalam belajar siswa (Caruth, 2019). Dengan demikian, pentingnya peranan guru dalam suatu pembelajaran mendorong guru untuk merancang suatu pembelajaran yang sesuai dengan karakteristik siswa.

Siswa perlu membiasakan dirinya dalam menyelesaikan masalah matematika yang realistis di sekitarnya (Zulkardi, 2002). Realistic Mathematics Education (RME) merupakan pembelajaran yang mengaitkan dengan masalah real sesuai dengan aktivitas manusia (pallinusa, 2013). RME sejalan dengan pemikiran pendidikan di Indonesia dimana siswa harus aktif selama pembelajaran berlangsung, dapat memecahkan masalah dan mengaplikasikannya dalam kehidupan sehari-hari (Sembiring, 2008). Pendekatan PMRI adalah salah satu pembelajaran yang sesuai dengan tujuan kurikulum 2013 dan menekankan pada konteks yang dibiasakan oleh siswa sebagai titik awal pembelajaran dalam pembentukan model, konsep, dan motivasi matematika sehingga akan membuat proses pembelajaran menjadi lebih berarti bagi siswa (Zulkardi \& Putri, 2006). RME memberikan siswa ruang dalam membangun pemahamannya dengan bimbingan guru. Kegiatan pemecahan masalah yang kontekstual dapat berdampak positif terhadap prestasi kognitif siswa terutama yang berkaitan dengan kemampuan mereka dalam memahami matematika (Laurens, 2018). Adapun prinsip RME yang terbagi menjadi tiga, yaitu penemuan terbimbing dan matematisasi berkelanjutan, fenomenologis didaktis, dan informal menuju formal (Pallinusa, 2013).

RME memiliki empat langkah, yaitu memahami masalah kontekstual, menyelesaikan masalah kontekstual, mendiskusikan dan membandingkan masalah kontekstual, dan menyimpulkan (Marini, 2017; Guler, 2018; Revina, 2018). RME dapat disimpulkan bahwa suatu pendekatan yang tidak hanya memberikan pemahaman matematika namun juga menumbuhkan diri siswa menjadi pribadi yang aktif, memecahkan masalah, menerapkannya kedalam kehidupan sehari-harinya. 
Kemandirian merupakan proses berpikir, merasakan, membuat pilihan, dan tindakan yang ingin dilakukan dengan cara mereka sendiri dalam mencapai suatu tujuan (Steinberg, 2014). Kemandirian belajar adalah suatu kegiatan yang mampu dalam menyelesaikan masalahnya sendiri dan memiliki kepercayaan diri tanpa bantuan orang lain (Prayekti, 2015). Kemandirian belajar juga merupakan upaya siswa dalam menyelesaikan permasalahan pada tugas yang diberikan selama proses belajar mengajar (Bozpolat, 2016). Kemandirian belajar ditekankan pada aktifitas belajar siswa yang dilakukan atas kemauannya, pilihannya, dan tanggung jawabnya sendiri (Meric, 2016). Akbar (2010) juga berpendapat bahwa pembelajaran nilai dan karakter dapat dikondisikan jika siswa berada di lingkungan dimana terdapat orang dapat menjadi teladan untuknya, termasuk guru. Kemandirian belajar siswa dapat terbentuk dengan adanya proses aktif dan konstruktif melalui hal-hal yang kontekstual (Çakir et al., 2016). Proses aktif akan memungkinkan siswa dalam melaksanakan pembelajaran disesuaikan dengan pengetahuan yang dimilikinya sehingga siswa dapat mandiri dalam belajarnya (Caruth, 2019). Kontekstual yang dimaksud yaitu dengan menghubungkan permasalahan di kehidupan sehari-hari siswa dengan materi yang akan dipelajari sehingga pembelajaran menjadi suatu pembelajaran yang bermakna bagi siswa (Pramudiani et al., 2011). Selain itu, kemandirian dapat didefinisikan sebagai suatu tindakan yang tidak bergantung dengan orang lain dalam menyelesaikan permasalahan terkait tugas belajarnya (Kemendiknas, 2010). Dengan demikian, kemandirian belajar mengacu cara belajar yang digunakan siswa dalam mencapai tujuan dengan tidak bergantung pada orang lain dan terdapat guru sebagai tauladan yang membimbing dalam suasana yang kontekstual.

Pentingnya kemandirian belajar yang harus dimiliki oleh siswa dalam pembelajaran matematika karena berdampak pada akademis siswa (Prayekti, 2015; Bozpolat, 2016). Begitu pula perlunya mengembangkan kemandirian belajar siswa untuk kepentingan masa depan siswa dalam hal belajarnya. Penelitian Laurens (2018) dan Debrenti (2016) menyatakan bahwa penerapan RME di kelas sangat berpengaruh terhadap pencapaian kognitif siswa dalam belajar daripada kelas yang masih menggunakan pembelajaran yang konvensional. Tidak hanya itu saja, RME juga membuat konsep matematika yang awalnya abstrak dapat dikemas menjadi lebih mudah dimengerti siswa. Selain itu, Laurens (2018) menyatakan penelitian yang dilakukan di beberapa negara (termasuk negara berkembang seperti Indonesia) telah membuktikan bahwa RME merupakan pendekatan yang menjanjikan untuk memperbaiki dan meningkatkan pemahaman siswa tentang konsep matematika. Papadakis (2017) juga berendapat dalam penelitiannya bahwa penerapan RME berpengaruh positif terhadap peningkatan prestasi akademik siswa, afektif siswa, minat siswa terhadap latihan, siswa dibebaskan dari hafalan dan dapat menghubungkannya konsep dengan kehidupan sehari-harinya. Selanjutnya pada penelitian Karaca (2017) menyatakan bahwa Realistic Mathematics Education (RME) tidak hanya meningkatkan prestasi dan sikap positif siswa namun juga meminimalisir kecemasan siswa terhadap pembelajaran matematika dan juga berdampak positif pada hasil belajar afektif.

Dari uraian di atas tentang kemandirian belajar matematika, maka penelitian ini mengembangkan beberapa indikator kemandirian belajar matematika siswa dengan menggunakan pendekatan RME, di antaranya (1) berani mengeluarkan pendapat, (2) berani bertanya, (3) berkontribusi dalam kelompok, (4) menemukan solusi/jawaban, dan (5) memperhatikan selama pembelajaran. Berani mengeluarkan pendapat dan bertanya merupakan kegiatan yang dilakukan siswa ketika siswa percaya diri dengan dirinya dan menunjukkan bahwa dirinya memiliki rasa ingin tahu. Berkontribusi dalam kelompok dan menemukan solusi/ jawaban merupakan kegiatan siswa yang menunjukkan bahwa dirinya bertanggung jawab kepada tugas yang diberikan oleh guru. Memperhatikan selama pembelajaran merupakan salah satu kegiatan siswa yang menunjukkan sikap keingintahuan siswa dalam memperoleh informasi yang dapat membantunya menyelesaikan tugas yang diberikan. Pernyataan tersebut membuat peneliti tertarik untuk melakukan penelitian yang berjudul Implementasi Realistic Mathematics Education (RME) untuk Meningkatkan Kemandirian Belajar Matematika .

\section{METODE}

Metode yang digunakan pada penelitian adalah penelitian tindakan kelas. Penelitian tindakan kelas menggunakan model Kemmis dan Mc Tagart dengan tahapan perencanaan, tindakan, observasi, dan refleksi (Mertler, 2014). Penelitian dilaksanakan di SDN Sumbertaman 1 Probolinggo dengan lokasi di jalan Sunan Giri Nomor 4 Kelurahan Sumbertaman Kecamatan Wonoasih Kota Probolinggo Provinsi Jawa Timur. Subjek penelitian ini terdiri dari 29 siswa kelas IV dengan jumlah siswa perempuan 15 dan siswa laki-laki 14. Latar belakang penelitian ini yaitu karena permasalahan guru yang terjadi dari tahun ke tahun dan ketika peneliti melakukan observasi awal pada materi luas dan keliling persegi dan persegi panjang.

Instrumen penelitian ini menggunakan lembar observasi kegiatan guru, lembar observasi kemandirian belajar siswa, angket, lembar kerja kelompok, dan pedoman wawancara. Penelitian ini di mulai pada bulan Agustus 2018 dan menggunakan dua siklus. Lembar observasi bertujuan untuk melakukan pengamatan terhadap pelaksanaan realistics mathematics education baik kegiatan yang dilakukan oleh guru maupun siswa. Data hasil observasi dianalisis dengan kriteria sangat kurang, kurang, cukup baik, baik, sangat baik dalam pelaksanaan pendekatan RME dengan kriteria keberhasilan tindakan yaitu pelaksanaan pembelajaran RME, observasi kemandirian belajar siswa, dan angket minimal berkategori "baik" dengan persentase rata-rata minimal sebesar $76 \%$ dari keseluruhan jumlah siswa. 


\section{HASIL}

Pendekatan RME yang dapat meningkatkan kemandirian belajar siswa memiliki karakteristik sebagai berikut. Langkah pembelajaran RME yang pertama yaitu memberikan permasalahan, guru memberikan permasalahan kontekstual kepada siswa dalam bentuk cerita berupa lisan ataupun tulisan tentang keliling dan luas pada bangun datar persegi dan persegipanjang. Selain itu, permasalahan yang diberikan memiliki permasalahan yang berbeda-beda setiap dua kelompoknya. Hal tersebut meminimalisir terjadinya kegiatan mencontek atau kerjasama antar kelompok. Selanjutnya, siswa memahami permasalahan yang diberikan baik dengan cara mendengarkan maupun membaca. Kemandirian belajar siswa yang muncul yaitu siswa berani mengungkapkan informasi yang diketahui dan berani bertanya terkait permasalahan yang mungkin kurang dimengerti. Siswa tidak hanya berani bertanya kepada teman satu kelompoknya, namun juga kepada guru.

Pada tahap menyelesaikan permasalahan, guru memberikan lembar kerja kelompok dan bantuan berupa media manipulatif. Sedangkan media yang digunakan terdiri dari tiga benda, yaitu kertas berpetak, geoboard, dan potongan kertas. Kertas berpetak dimanfaatkan dengan cara menempelkan gambar buah atau sayur yang sudah disediakan guru dan menggambar benda untuk menandai keliling dan luas yang sesuai dengan tugas yang diberikan. Geoboard dimanfaatkan dengan cara membentuk luas dan keliling yang sesuai, pada pilar-pilar paku yang ada dengan menggunakan karet, sedangkan potongan kertas warna-warni dimanfaatkan dengan cara menyusun potongan kertas tersebut seperti puzzle sehingga membentuk bangun datar yang sudah ditentukan. Dengan adanya bantuan media manipulatif tersebut dapat memudahkan siswa dalam menyelesaikan tugas yang diberikan. Siswa secara kelompok menyelesaikan permasalahan yang diberikan. Kemandirian belajar siswa pada tahap ini juga muncul seperti siswa terlihat lebih berkontribusi dalam kelompok dan menyelesaikan tugas yang diberikan. Siswa juga terlihat saling sharing informasi satu sama lainnya. Terlihat beberapa siswa bertanya kepada sesama teman kelompoknya sedangkan siswa lainnya menjelaskan atau berani mengeluarkan pendapatnya kepada siswa lain yang kurang memahami tugas yang diberikan.

Tahap mendiskusikan dan membandingkan, guru mengajak siswa mendiskusikan dan membandingkan hasil pekerjaan kelompok yang telah siswa kerjakan bersama kelompoknya. Setiap dua kelompok mempresentasikan hasilnya di depan kelas dengan perwakilan dua orang. Awalnya beberapa siswa kurang berani dalam mempresentasikan hasil pekerjaannya di depan kelas. Namun guru berusaha untuk membimbing siswa dalam mempresentasikan hasilnya dan tidak menyalahkan pendapat siswa ketika presentasi. Siswa pun mulai berani dan berebut untuk mempresentasikan hasil kerja kelompok. Setelah presentasi, guru memberikan beberapa pilihan kartu pertanyaan kepada beberapa siswa yang tidak presentasi. Pertanyaan tersebut akan dibacakan oleh kelompok yang presentasi dan bersifat fleksibel sehingga dapat disesuaikan dengan hasil pekerjaan kelompok yang presentasi. Kelompok yang menjawab pertanyaan tersebut yaitu kelompok yang tidak presentasi. Dengan demikian, tidak hanya kelompok yang presentasi yang ditumbuhkan kemandiriannya namun juga kelompok yang tidak presentasi pun juga dapat mengembangkan kemandiriannya. Hal tersebut terlihat ketika siswa berani dalam mengungkapkan pendapatnya dan berani bertanya jika ada yang belum dimengerti.

Tahap menyimpulkan, guru membimbing siswa dalam menyimpulkan pembelajaran yang sudah siswa pelajari. Guru memancing siswa dengan memberikan beberapa pertanyaan terbimbing. Pertanyaan tersebut dapat mengajak siswa dalam mengutarakan pendapatnya tentang pembelajaran yang sudah dipelajari. Siswa lain juga dapat membantu melengkapi pendapat siswa lain yang mungkin kurang lengkap. Dengan demikian siswa dapat terpacu untuk berani mengungkapkan pendapatnya ataupun bertanya terkait pembelajaran yang masih belum dipahami.

Hasil refleksi setelah pelaksanaan siklus I yaitu dengan melakukan wawancara dengan siswa dan guru kelas terkait tugas yang diberikan menyatakan bahwa kemandirian siswa meningkat namun belum mencapai kriteria ketuntasan. Hal tersebut mungkin dikarenakan (1) guru kelas berpendapat bahwa pembelajaran sudah dikemas dengan baik oleh guru, namun kemandirian masih kurang begitu muncul ketika siswa mempresentasikan hasil pekerjaan kelompoknya. Dalam memperbaiki hal tersebut, guru dapat memberikan kuis dimana pertanyaannya sesuai dengan hasil yang telah dikerjakan oleh siswa karena siswa menyukai sesuatu hal dimana siswa berkompetisi antar kelompok; (2) guru kelas juga berpendapat bahwa perlunya guru dalam memberikan waktu kepada siswa dalam mengerjakan tugas yang diberikan sehingga waktu pembelajaran sesuai dengan waktu yang telah direncanakan pada RPP; (3) beberapa siswa terlihat melakukan aktivitas menggambar, mungkin pada siklus selanjutnya terdapat media dimana siswa menggambar; (4) siswa berpendapat lebih terbantu dengan adanya media manipulatif dalam mengerjakan tugasnya, namun beberapa siswa merasa media potongan kertas yang harus ditempelkan terlalu banyak.

Refleksi yang sudah dipaparkan sebelumnya menunjukkan bahwa perlu adanya penambahan siklus karena kemandirian belajar siswa masih belum mencapai batas minimal dari indikator keberhasilan yang sudah ditetapkan. Adapun tindak lanjut untuk siklus II yaitu (1) memberikan kuis pada langkah mendiskusikan dan membandingkan jawaban; (2) memberikan batasan waktu yang jelas terhadap siswa dalam mengerjakan tugasnya sehingga waktu tidak melampaui dari waktu yang telah ditentukan; (3) tidak adanya kegiatan menempel pada media potongan kertas, kegiatan menempel menggambar pada media kertas berpetak.

Hasil refleksi setelah pelaksanaan siklus II yaitu melakukan wawancara dengan siswa dan guru kelas terkait tugas yang diberikan. Pertama, dengan menggunakan ketiga media, siswa merasa terbantu dalam menemukan atau mengecek kebenaran dari tugas yang diberikan. Menurut siswa, papan geoboard merupakan media yang paling menarik karena memiliki keunggulan, yaitu untuk menemukan jawaban siswa hanya perlu memindahkan karet sehingga tidak memerlukan waktu yang lama. Sementara itu, pada kertas berpetak, siswa perlu menempelkan potongan kertas lalu memberi garis pada kertas berpetak tersebut. Lalu pada potongan kertas, siswa hanya perlu memindahkannya potongan kertas sesuai dengan keliling atau luas yang ingin dicari. Kedua, 
guru kelas berpendapat bahwa pembelajaran sudah dikemas dengan baik oleh guru. Ketiga, mencapai kriteria ketuntasan minimal dengan 82\% (24 siswa) mencapai kategori "baik", angket dengan 83\% dengan kategori baik, dan hasil pelaksanaan pembelajaran RME mencapai persentase 95\% dengan kategori "sangat baik". Kemandirian dapat mencapai kriteria ketuntasan tindakan karena guru menyajikan pembelajaran dengan langkah RME berbantuan media manipulatif yang menarik, permasalahan yang dikemas dalam bentuk cerita tertulis dan lisan dan tugas yang memiliki jawaban/solusi yang bervariasi.

\section{PEMBAHASAN}

Penerapan pendekatan RME dalam pemberian tugas luas dan keliling persegi dan persegipanjang, dimaksudkan untuk meningkatkan kemandirian belajar matematika siswa. Kemandirian dapat meningkat secara signifikan karena terdapat bantuan media manipulatif (kertas berpetak, geoboard, dan potongan kertas), permasalahan dalam bentuk cerita tertulis dan lisan dan tugas yang memungkinkan siswa dalam berkompetisi antar kelompok dengan jawaban yang berbeda-beda. Kemandirian belajar yang diamati yaitu (1) berani bertanya; (2) berani mengeluarkan pendapat; (3) berkontribusi dalam kelompok; (4) berusaha menemukan jawaban/solusi; (5) memperhatikan selama pembelajaran.

\section{Pemberian Masalah}

Guru memberikan permasalahan dalam bentuk cerita kontekstual secara lisan dan tertulis. Permasalahan tersebut memungkinkan siswa dalam menemukan berbagai jawaban ataupun cara sehingga setiap kelompok dapat menemukan jawaban yang bervariasi. Dengan permasalahan yang berbeda, meminimalisir terjadinya kerjasama antar kelompok satu dengan yang lainnya. Hal tersebut dapat mengembangkan kemandirian belajar pada diri siswa seperti lebih fokus dalam menyelesaikan permasalahan karena memiliki rasa ingin tahu yang lebih terhadap tugas yang diberikan dan mencari cara penyelesaiannya. Pada tahap ini, guru membagi siswa menjadi enam kelompok, dimana setiap dua kelompok memiliki permasalahan yang berbeda. Selain itu, guru memberikan satu lembar kerja kelompok pada setiap kelompok, dan memberikan media manipulatif (kertas berpetak, papan geoboard, dan potongan kertas berpetak) guna membantu siswa dalam menyelesaikan permasalahan yang telah diberikan. Pernyataan di atas didukung oleh pendapat As'ari (2013) bahwa pembelajaran harus ditekankan pada pembelajaran yang mendukung siswa dalam tumbuh kembangnya dan kemampuannya dalam bekerjasama sehingga kelompok terlihat saling berdiskusi tentang permasalahan yang diberikan dan tentang bagaimana cara menyelesaikannya. Çakir (2016) berpendapat bahwa kemandirian belajar siswa dapat terbentuk dengan adanya proses aktif dan konstruktif melalui hal-hal yang kontekstual. Selain itu, Altintas (2018) mengatakan bahwa pengajaran matematika melalui cerita membantu siswa untuk lebih beradaptasi dengan mata pelajaran, untuk lebih mudah mempelajari mata pelajaran.

\section{Menyelesaikan Permasalahan}

Siswa menggunakan media (kertas berpetak, papan geoboard, dan potongan kertas berpetak) untuk membantunya dalam menyelesaikan tugas yang diberikan dan menuliskan hasilnya pada lembar kerja kelompok. Pada dasarnya media digunakan tidak hanya agar memudahkan siswa dalam mengerjakan permasalahan yang diberikan, namun juga agar siswa secara perlahan dapat mengontruksikan konsep dari pengetahuan sebelumnya dengan pengetahuan baru. Dalam proses tersebut, siswa memunculkan sikap kemandirian yaitu berani bertanya, berani berpendapat, berusaha dalam menemukan jawaban/solusi, dan berkontribusi dalam kelompok. Selain itu, penyelesaian masalah dengan menggunakan media manipulatif, siswa terlihat lebih berkontibusi dalam kelompok dan tumbuhnya interaksi antar siswa, antara kelompok dengan kelompok, dan antar guru dengan siswa. Hal tersebut paralel dengan pendapat Hidayah (2018) bahwa penggunaan manipulatif yang diintegrasikan ke dalam pembelajaran matematika yang dibantu dengan permasalahan lisan dan tertulis efektif dan praktis untuk meningkatkan pemahaman siswa terhadap materi tersebut. Selain itu, Zulkardi (2002) juga berpendapat siswa yang memiliki kebebasan dalam mendiskusikan strategi yang digunakan untuk menyelesaikan masalah yang diberikan oleh guru akan berdapak positif pada diskusi dalam kelompok yang dapat menciptakan situasi alami yang disebut interaksi sosial.

Siswa terlihat berani bertanya dibuktikan dengan siswa merasa ingin tahu lebih jelas maksud dari permasalahannya sehingga dapat mengetahui cara menyelesaikannya. Siswa terlihat berani berpendapat dibuktikan dengan siswa yang terlihat berdiskusi tentang cara menyelesaikan permasalahan yang diberikan dan membantu menjelaskan kepada siswa lain yang belum memahaminya. Berusaha menemukan jawaban dan berkontribusi dalam kelompok dibuktikan dengan pembagian tugas dalam menyelesaikan permasalahan dan sharing tentang jawaban yang telah ditemukan oleh masing-masing anggota kelompok. Selain itu, siswa yang terlihat bersama-sama berkumpul menjadi satu dalam menggunakan media yang disediakan. Hal tersebut sesuai dengan prinsip RME yang kedua yaitu didactical phenomenology, konsep matematika yang diberikan berasal dari fenomena yang dekat dengan siswa. Hal tersebut memungkinkan siswa dalam menggunakan pengalaman sebelumnya secara langsung dan dilakukan secara interaktif baik antara siswa dan siswa maupun antara siswa dan guru. Hal tersebut sejalan dengan pendapat Furner (2017) bahwa kognitif dapat terbentuk ketika guru membimbing siswa dalam membuat koneksi antara pengetahuan baru dengan pengetahuan yang ada dan antara konsep matematika dengan kegiatan langsung. Putri, Dolk, \& Zulkardi (2011) menyatakan bahwa guru yang menggunakan beberapa kegiatan termasuk norma sosial di kelas, seperti membimbing siswa untuk bertanya dan berdebat dapat mengaktifkan interaksi sosial siswa. 
Penyelesaian masalah secara berkelompok juga dapat memberikan kesempatan kepada siswa untuk saling membantu satu sama lain serta masukan dalam menemukan suatu konsep. Anggota kelompok yang mungkin kurang bisa dapat lebih percaya diri dalam bertanya kepada anggota kelompoknya yang dirasa lebih paham daripada dirinya. Siswa yang sudah paham telah bertambah pemahamannya ketika menjelaskan kepada angggota yang kurang bisa. Penyelesaian masalah secara berkelompok juga dapat memberikan kesempatan kepada siswa untuk saling membantu satu sama lain serta masukan dalam menemukan suatu konsep. Hal itu didukung oleh pendapat Iskandar \& Sa'dijah (2003) bahwa kemampuan bekerja sama sangat penting dalam menghadapi era globalisasi dan penugasan seharusnya dapat dijangkau oleh siswa yang disesuaikan dengan kemampuan yang dimiliki siswa yang tidak terlalu mudah tetapi juga tidak terlau sulit (As'ari, 2015). Ababneh (2017) dan Alfares (2017) bahwa kegiatan kerja kelompok dapat memungkinkan siswa untuk lebih mandiri karena anggota kelompok didorong untuk mengajar orang lain dan juga belajar dari orang lain.

Siswa yang merasa kesulitan menyelesaikan permasalahan, guru akan memberinya kesempatan untuk memahami kembali permasalahan yang ada lalu mengajukan beberapa pertanyaan yang akan menuntunnya dalam menemukan solusi dari permasalahan tersebut. Pada prinsip ini, yang diterapkan adalah guided reinvention and progress yaitu siswa diberi kesempatan untuk mengalami proses menemukan berbagai konsep matematika yang ditemukan dengan bimbingan guru. Kegiatan ini sejalan dengan pendapat Freudenthal bahwa pembelajaran matematika yang dipelajari karena matematika merupakan aktivitas manusia dan bukanlah suatu ilmu yang dipindah dari guru ke siswa. Hal ini sejalan dengan pendapat Caruth (2019) bahwa proses aktif yang memungkinkan siswa dalam memahami pembelajaran sesuai pengetahuan yang dimiliki sehingga pembelajaran menjadi bermakna bagi siswa (Pramudiani, 2011) dapat memengaruhi kemandirian belajar siswa.

\section{Mendiskusikan dan Membandingkan Jawaban}

Pada tahap ini, siswa dapat mempresentasikan hasil diskusi kelompok. Presentasi dilakukan oleh dua kelompok yang mendapatkan permasalahan sama dengan perwakilan dua siswa pada masing-masing kelompok. Peran guru hanya sebagai mediator yang mengarahkan pemikiran siswa apabila diskusi terkesan pasif atau melenceng dari topik yang sedang dibahas. Selain itu, guru juga tidak menyalahkan pendapat yang diberikan siswa ataupun perbedaan hasil pada dua kelompok yang sedang presentasi. Guru hanya mengajak siswa mendiskusikan bersama-sama perihal perbedaan pendapat yang muncul ketika presentasi berlangsung. Hal tersebut dilakukan agar kelompok yang presentasi dapat lebih percaya diri dalam mengungkapkan pendapatnya di depan teman-temannya. Setelah kelompok mempresentasikan, guru memberikan beberapa pilihan kartu soal dimana soal tersebut nantinya akan diberikan kepada kelompok yang tidak presentasi. Pertanyaan pada kartu soal bersifat fleksibel sehingga dapat disesuaikan dengan hasil pekerjaan pada masing-masing kelompok. Hal ini dilakukan agar kelompok yang tidak presentasi juga dapat lebih berani dalam mengungkapkan pendapatnya dan membandingkan jawabannya dengan kelompok yang presentasi. Pernyataan sebelumnya sejalan dengan pendapat Gravemeijer and Eerde (2009) bahwa selama proses pembelajaran siswa memiliki kewajiban untuk berpikir dengan pemikirannya sendiri untuk menjelaskan dan membenarkan solusi yang telah ditemukan serta mencoba dan memahami alasan dari siswa lain dan mengajukan pertanyaan tentang penjelasan yang tidak dipahami, dan argumen yang tidak disetujui.

Diskusi kelas berjalan dengan menarik karena terdapat perbedaan ide dalam menjawab masalah yang disajikan. Kelompok penyaji sudah berani mengutarakan pendapatnya. Dua kelompok penyaji menjelaskan pendapatnya lalu kelompok lain dapat membandingkan hasil yang didapat dari dua kelompok penyaji. Selain itu, kelompok penyaji juga memberikan soal kepada kelompok lain untuk menguji perhatian siswa selama presentasi dan agar kelompok lain dapat menumbuhkan kemandiriannya dengan berani mengeluarkan pendapat. Kelompok yang tidak presentasi terlihat berani dalam memberikan pendapatnya sehingga terjadi interaksi antara siswa dan siswa serta antara guru dan siswa. Meskipun terkadang komentar atau pendapat yang diutarakan oleh siswa masih bersifat informal, namun guru tetap menghargai kontribusi siswa. Kondisi ini dapat meningkatkan kemandirian belajar siswa, meliputi berani mengeluarkan pendapat, berani ketika bertanya, berkontribusi dalam kelompok dan berusaha menemukan jawaban/solusi, dan memperhatikan selama pembelajaran. Hal tersebut sejalan dengan pendapat (Meric and Ilhan, 2016) bahwa kemandirian belajar ditekankan pada aktivitas belajar siswa yang dilakukan atas kemauannya, pilihannya, dan tanggung jawabnya sendiri dimana siswa dapat mengekspresikan tanpa ada perasaan takut atau terancam dari pihak lain seperti guru ataupun siswa lain. Selain itu, As'ari (2017) juga berpendapat bahwa dengan adanya kerjasama dapat menimbulkan suasana yang sebelumnya belum pernah muncul karena mungkin saja hal tersebut dapat muncul karena terdapat anggota kelompok yang dapat menginspirasi bagi anggota kelompok lain ketika memecahkan suatu masalah bersama.

\section{Menyimpulkan}

Pada tahap ini, guru mengarahkan siswa membuat kesimpulan terkait permasalahan atau tugas yang telah diberikan. Kesimpulannya berkaitan tentang bagaimana cara masing-masing kelompok dalam menyelesaikan permasalahan tersebut. Guru akan memberikan pertanyaan yang membimbing siswa ketika siswa merasa kesulitan dalam menyimpulkan terkait tugas yang sudah diberikan. Selain itu, guru tidak pernah menyalahkan pendapat ketika siswa memiliki pendapat yang kurang tepat atau kurang sesuai. Pada tahap ini, siswa terlihat semakin percaya diri dalam mengemukakan pendapatnya. Hal tersebut dibuktikan dengan guru yang semakin sedikit dalam memberikan pertanyaan untuk membantu siswa menyimpulkan terkait tugas yang sudah dikerjakan. Hal tersebut sesuai dengan pendapat Anwar (2016) bahwa siswa yang memiliki kepercayaan diri yang tinggi memiliki keberanian untuk mengambil resiko dalam berbicara. 


\section{SIMPULAN}

Penerapan pendekatan Realistic Mathematics Education (RME) dapat meningkatkan kemandirian belajar matematika siswa SDN Sumbertaman 1 Probolinggo pada materi luas dan keliling persegi dan persegipanjang. Kemandirian dapat mencapai kriteria ketuntasan tindakan karena guru menyajikan pembelajaran dengan langkah pada pendekatan RME berbantuan media manipulatif yang menarik, dan tugas yang memiliki jawaban yang bervariasi. Berikut tahapan RME yang dapat meningkatkan kemandirian belajar siswa. Pertama, pada tahap pemberian masalah, guru memberikan permasalahan dalam bentuk cerita secara lisan dan tertulis pada masing-masing kelompok dimana setiap dua kelompok mendapatkan permasalahan yang berbeda. Selain itu, tugas yang diberikan dapat diselesaikan dengan berbagai cara ataupun dengan jawaban yang beragam. Kedua, guru memberikan media manipulatif (papan geoboard, potongan kertas, dan kertas berpetak) dengan warna-warna yang menarik. Media manipulatif dapat membantu siswa dalam menyelesaikan tugas yang diberikan ataupun menemukan konsep lain. Selain itu, dapat mempermudah siswa dalam menyelesaikan tugas yang diberikan. Selanjutnya, setiap kelompok menuliskan temuan/ jawabannya pada lembar kerja kelompok. Ketiga, tahap mendiskusikan dan membandingkan, siswa mempresentasikan hasil kerja kelompok dengan perwakilan dua siswa pada setiap kelompok. Setiap presentasi, dua kelompok yang memiliki permasalahan/ tugas yang sama mempresentasikan hasilnya secara bersamaan. Guru hanya sebagai fasilitator siswa yang tidak pernah menyalahkan siswa ketika terdapat pendapat yang kurang tepat. Ketika terdapat pendapat yang kurang tepat, guru akan mengajak siswa lainnya mendiskusikannya secara bersama-sama. Hal demikian dilakukan agar siswa tidak takut atau merasa terintimidasi ketika mengungkapkan pendapatnya. Setelah presentasi, guru mengajak kelompok yang tidak presentasi untuk berkompetisi antar kelompok dengan memberikan kartu soal dimana kartu tersebut akan dibacakan oleh kelompok yang sedang presentasi. Soal yang diberikan bersifat fleksibel, jadi dapat disesuaikan dengan hasil kerja kelompok yang sedang presentasi. Keempat, tahap menyimpulkan, guru membantu siswa dalam menyimpulkan kegiatan mulai awal hingga akhir pembelajaran. Guru membantu siswa dengan cara memberikan beberapa pertanyaan yang dapat membantu siswa dalam menyimpulkan kegiatan yang telah dilakukan.

Adapun beberapa saran terkait temuan pada penelitian sebagai berikut. Pertama, pendekatan realistic mathematics education dapat meningkatkan kemandirian belajar matematika siswa pada materi luas dan keliling persegi dan persegipanjang. Oleh karena itu, dapat dijadikan salah satu alternatif pendekatan pada materi matematika yang lain di Sekolah Dasar. Kedua, penggunaan pendekatan Realistic Mathematics Education dengam menggunakan media manipulatif seperti geoboard, kertas berpetak, dan potongan kertas dapat membuat siswa tertarik dalam menyelesaikan tugas yang diberikan. Oleh karena itu, guru sebaiknya menggunakan media manipulatif yang menarik dalam membantu siswa menyelesaikan tugas yang diberikan. Ketiga, perlunya guru dalam memberikan soal kontekstual dan memungkinkan siswa dalam menemukan jawaban yang bervariasi sehingga siswa dapat mengonstruk pengetahuan yang dimiliki. Keempat, pendekatan RME memberikan kebebasan siswa dalam menghubungkan pengetahuan lama yang dimiliki siswa dengan pengetahuan yang baru sehingga membutuhkan waktu yang cukup lama dalam menemukan solusi terkait tugas yang diberikan. Dalam menanggulangi hal tersebut, perlunya guru dalam mengelola waktu sebaik mungkin agar pembelajaran dapat berjalan sesuai dengan waktu yang telah ditentukan. Kelima, pendekatan RME dinilai efektif dalam meningkatkan sikap kemandirian siswa sehingga peneliti lain mungkin dapat meneliti kemandirian belajar siswa dalam aspek lainnya.

\section{DAFTAR RUJUKAN}

Ababneh, S. (2017). Attitudes of Jordanian Students Towards Using Group Work in EFL Classrooms. Advances in Language and Literary Studies, 8(1), 233. doi: 10.7575/aiac.alls.v.8n.1p.233.

Akbar, S. (2010). Model Pembelajaran Nilai dan Karakter Berbasis Nilai-Nilai Kehidupan di Sekolah Dasar. Jurnal Ilmu Pendidikan, 17(1), 46-54.

Alfares, N. (2017). Benefits and Difficulties of Learning in Group Work in EFL Classes in Saudi Arabia. English Language Teaching, 10(7), 247. doi: 10.5539/elt.v10n7p247.

Altintas, E. (2018). Analyzing Students Views about Mathematics Teaching Through Stories and Story Generation Process. Educational Research and Reviews, 13(7), 249-259. doi: 10.5897/err2018.3498.

As'ari, A. R. (2013). Mewujudkan Pendekatan Saintifik Dalam Kelas Matematika. Conference Paper (March 2014), 1-21. doi: 10.1007/s11684-016-0473-8.

As'ari, A. R. (2017). Tantangan Pengembangan Profesionalisme Guru dalam Rangka Membelajarkan Matematika di Abad ke21 dan Membangun Karakter Peserta Didik. in Tantangan Pengembangan Profesionalisme Guru Dalam Rangka Membelajarkan Matematika di Abad Ke-21 dan Membangun Karakter Peserta Didik, pp. 43-56.

Bozpolat, E. (2016). Investigation of the Self-Regulated Learning Strategies of Students from the Faculty of Education Using Ordinal Logistic Regression Analysis. Kuram ve Uygulamada Egitim Bilimleri, 16(1), 301-318. doi: 10.12738/estp.2016.1.0281.

Çakir, R. et al. (2016). An Exploration of the Relationship Between Students Preferences for Formative Feedback and SelfRegulated Learning Skills. Journal of Educational Sciences, 4(4), 14-30.

Caruth, G. (2019). Automated Test Paper Generation Using Utility Based Agent and Shuffling Algorithm. International Journal of Web-Based Learning and Teaching Technologies, 14(1), 69-83. doi: 10.4018/IJWLTT.2019010105.

Crain, W. (2007) Teori Perkembangan: Konsep dan Aplikasi. Edited by Y. Santoso. Yogyakarta: Pustaka Pelajar. 
Debrenti, E. (2016). Some Components of Geometric Knowledge of Future Elementary School Teachers. Acta Didactica Napocensia, 9(3), 11-20. doi: 10.1177/0893318904267721.

Furner, J. M., \& Worrell, N. L. (2017). The Importance of Using Manipulatives in Teaching Math Today. Transformations, $3(1), 1-25$.

Gravemeijer, K., \& Eerde, D. V. (2009). Design Research as a Means for Building a Knowledge Base for Teachers and Teaching in Mathematics Education. The Elementary School Journal, 109(5), 510-524.

Guler, H. (2018). Activities Written by Prospective Primary Teachers on Realistic Mathematics Education. International Journal of Evaluation and Research in Education, 7(3), 229-235. doi: 10.11591/ijere.v7.i3.pp229-235.

Hidayah, I., Dwijanto., \& Istiandaru, A. (2018). Manipulatives and Question Series for Elementary School Mathematics Teaching on Solid Geometry. International Journal of Instruction, 11(3), 649-662.

Iskandar, S. M., \& Sa'dijah, C. (2003). Persepsi dan Pengetahuan Guru Kelas-kelas Awal Sekolah Dasar di Jawa Timur terhadap Pembelajaran Terpadu dalam Bidang MIPA. Jurnal Penelitian Kependidikan, 13(1).

Karaca, Y., \& Ozkaya, A. (2017). The Effects of Realistic Mathematics Education on Students' Math Self Reports in Fifth Grades. International Journal of Curriculum and Instruction, 9(1), 81-103.

Kemendiknas. (2010). Pengembangan Pendidikan dan Karakter Bangsa. Jakarta: Kementrian Pendidikan Nasional.

Laurens, T. et al. (2018). How Does Realistic Mathematics Education (RME) Improve Students' Mathematics Cognitive Achievement?. Eurasia Journal of Mathematics, Science and Technology Education, 14(2), 569-578. doi: 10.12973/ejmste/76959.

Marini., As'ari, A. R., \& Chandra, T. D. (2017). Peningkatan Motivasi Belajar Siswa melalui Penerapan Pendekatan Realistic Mathematics Education. Jurnal Pendidikan: Teori, Penelitian, dan Pengembangan, 2(4), 470-477.

Meric, O., \& Ilhan, A. (2016). Does 12-Week Latin Dance Training Affect the Self-Confidence of the University Students?'. Journal of Education and Learning, 5(4),159-164. doi: 10.5539/jel.v5n4p159.

Mertler, C. (2014) Action Research. Edited by Benyamin Molan. Yogyakarta: Pustaka Pelajar.

Pallinusa, A. L. (2013). Students' Critical Mathematical Thinking Skills and Character: Experiments for Junior High School Students Through Realistic Mathematics Education Culture-Based. Indonesian Mathematical Society Journal on Mathematics Education, 4(1), 75-94. doi: 10.22342/jme.4.1.566.75-94.

Papadakis, S., Kalogiannakis, M., \& Zaranis, N. (2017). Improving Mathematics Teaching in Kindergarten with Realistic Mathematical Education. Early Childhood Education Journal, 45(3), 369-378. doi: 10.1007/s10643-015-0768-4.

Pramudiani, P. et al. (2011). A Concrete Situation for Learning Decimals. Journal of Mathematics Education, 2(2), $215-230$.

Prayekti. (2015). Effect of Self-Regulated Learning and Motivation to Achieve Against Teacher Professional Capability for Student S1 PGSD of Science Field Compared with Regular Student S1 PGSD at UPBJJ Serang. Journal of Education and Practice, 6(36), 47-55.

Putri, R. I. I., Dolk, M., \& Zulkardi. (2011). Professional Development of PMRI Teachers for Introducing Social Norms. Journal on Mathematics Education, 6(1), 11-19.

Revina, S. (2018). How the Same Flowers Grow in Different Soils? The Implementation of Realistic Mathematics Education in Utrecht and Jakarta Classrooms. International Journal of Science and Mathematics Education. doi: 10.1007/s10763-0189883-1.

Sa'dijah, C. (2011). Kemampuan Partisipasi dan Kerjasama Siswa dalam Pembelajaran Matematika Beracuan Konstruktivis dengan Setting Koperatif. Semnastika-Unesa "Matematika Membangun Insan Kritis dan Kreatif, p. 69.

Sa'dijah, C. (2013). Kepekaan Bilangan siswa SMP melalui Pembelajaran Matematika Kontekstual dan mengintegrasikan Ketrampilan Berpikir Kreatif. Jurnal Pendidikan dan Pembelajaran, 20(2), 222-227.

Sembiring, R., Hadi, S., \& Dolk, M. (2008). Reforming Mathematics Learning in Indonesian Classrooms Through RME. International Journal on Mathematics Education, 40(6), 927-939. doi: 10.1007/s11858-008-0125-9.

Steinberg, M. P. (2014). Does greater autonomy improve school performance? Evidence from a Regression Discontinuity Analysis in Chicago. Education Finance and Policy. doi: 10.1162/EDFP_a_00118.

Vula, E. et al. (2017). The Impact of Metacognitive Strategies and Self-Regulating Processes of Solving Math Word Problems', International Electronic Journal of Elementary Education, 10(1), 49-59. doi: 10.26822/iejee.2017131886.

Walle, J. (2008). Sekolah Dasar dan Menengah Matematika. 6th ed. Edited by Suyono. Jakarta: Erlangga.

Zulkardi. (2002). Developing a Learning Environment on Realistic Mathematics Education for Indonesian Student Teachers, Dissertation. Available at: http://eprints.unsri.ac.id/615/1/thesis_Zulkardi.pdf. 